\title{
Pertumbuhan dan Hasil Dua Varietas Ubi Kayu pada Empat Dosis Pupuk Npk di Lahan Pasang Surut Kalimantan Selatan
}

\author{
Growth and Yield of Two Varieties of Cassava at Four Doses of Npk Fertilizer in Tidal \\ Land, South Kalimantan
}

\author{
Sutrisno $^{1}$, Sri Wahyuningsih ${ }^{2}$ \\ ${ }^{1,2}$ Balai Penelitian Tanaman Aneka Kacang dan Umbi
}

\begin{tabular}{l} 
ARTICLE INFO \\
\hline Article history: \\
DOI: \\
10.30595/pspfs.v2i.174 \\
Submitted: \\
July 29, 2021 \\
Accepted: \\
Sept 10, 2021 \\
Published: \\
Nov 10, 2021 \\
\hline
\end{tabular}

Keywords:

Tidal Land, NPK Fertilizer, Cassava

\begin{abstract}
Tidal acid land is a potential land for cassava development. However, the development of cassava in tidal land faces many obstacles, one of which is the low availability of nutrients. This study aimed to determine the effect of NPK fertilizer in increasing the growth and yield of cassava in tidal land. The experiment consisted of two factors, the first factor was two varieties of cassava and the second factor was four levels of NPK fertilizer doses. The experiment was applied in a strip plot design with variety as the horizontal factor and the level of NPK fertilizer as the vertical factor and repeated three times. The growth parameters observed consisted of plant height, stem diameter, plant biomass weight, number of large tubers, number of small tubers, large tuber length, length of small tuber, the diameter of large tuber, the diameter of small tuber, the total number of tubers, the weight of large tuber, the weight of tuber small, and total tuber weight. The results showed that fertilizer application was effective in increasing vegetative growth and yield of cassava but increasing the dose of fertilizer was not effective in increasing the growth and yield of cassava. Differences in varieties generally did not show differences in vegetative growth and some yield components but still showed different results in the components of tuber length and total tuber weight.
\end{abstract}

This work is licensed under a Creative Commons Attribution 4.0 International License.

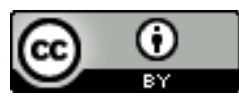

Corresponding Author:

Sutrisno

Balai Penelitian Tanaman Aneka Kacang dan Umbi

Jl. Raya Kendalpayak. KM 8. Kotak Pos 66 Malang

Email: uthisharun@gmail.com

\section{PENDAHULUAN}

Ubikayu merupakan salah satu tanaman pangan penyangga sumber karbohidrat penting bagi kebanyakan masyarakat di pedesaan Indonesia. Tanaman ubikayu menghasilkan kalori sebesar $250 \mathrm{kkal} / \mathrm{ha} / \mathrm{hari}$, jauh lebih tinggi jika dibandingkan dengan tanaman sereal seperti padi yang menghasilkan $176 \mathrm{kkal} / \mathrm{ha} / \mathrm{hari}$, gandum yang menghasilkan $110 \mathrm{kkal} / \mathrm{ha} / \mathrm{hari}$ ataupun jagung yang menghasilkan $200 \mathrm{kkal} / \mathrm{ha} / \mathrm{hari}$. Ubikayu juga mengandung berbagai nutrisi seperti mineral dan vitamin. Karakteristik utama tanaman ubi kayu adalah kemampuannya untuk tumbuh dan berproduksi pada kondisi tanah yang tingkat kesuburannya rendah (James dan Byju, 2010). Permintaan ubi kayu dari tahun ke tahun mengalami peningkatan, baik untuk dikonsumsi langsung maupun sebagai bahan baku berbagai industri. Saat ini produksi ubikayu belum mampu mencukupi kebutuhan nasional, secara umum keragaan produksi dan produktivitas selama 5 tahun terakhir (2010-2015) menunjukkan pertumbuhan yang positif meskipun dengan luas tanam yang berfluktuasi. Pada tahun 2015 produksi ubi kayu 
tercatat sebanyak 21,80 juta ton dengan luas panen sekitar 900 ribu ha, atau produktivitas rata-rata sekitar 22,95 ton/ha (BPS, 2016). Produktivitas ubi kayu tersebut masih jauh dari potensi hasil beberapa varietas unggul ubi kayu yang dapat mencapai 40-50 ton/ha (Saleh, 2012).

Secara teknis upaya peningkatan produksi ubikayu di Indonesia dapat dicapai melalui peningkatan produktivitas dan perluasan tanaman ubikayu. Namun demikian, upaya peningkatan produksi ubi kayu tersebut belum tentu berhasil apabila produktivitas dan luas panen ubi kayu yang dicapai petani telah sebanding atau sangat mendekati potensinya. Untuk meningkatkan produksi pangan, terutama komoditas ubikayu dan untuk memenuhi kebutuhan nasional, upaya yang perlu dilakukan adalah melalui pengembangan di lahan suboptimal, yaitu lahan pasang surut. Lahan suboptimal adalah lahan yang telah mengalami degradasi dan kesuburan tanahnya rendah sehingga tidak mampu mendukung pertumbuhan tanaman secara optimal (Balai Penelitian Tanah 2012).

Saat ini lahan pasang surut yang tersedia untuk pengembangan tanaman pangan mencapai 773 ribu ha. Namun tidak semua lahan tersebut clear dan clean karena sebagian besar sudah dimanfaatkan untuk berbagai penggunaan, diantaranya sebagai hutan produksi (HP) seluas 446 ribu ha, kawasan hutan konversi (KHK) 103 ribu ha, dan area penggunaan lain (APL) 224 ribu ha (Mulyani et al. 2017). Menurut jangkauan airnya, lahan pasang surut dibedakan ke dalam empat tipe luapan, yaitu 1) tipe A, lahan yang selalu terluapi air pasang, baik pasang besar (springtide) maupun pasang kecil (neaptide), 2) tipe B, lahan yang hanya terluapi oleh pasang besar, 3) tipe $\mathrm{C}$ lahan yang tidak pernah terluapi walaupun pasang besar, air pasang memengaruhinya secara tidak langsung, kedalaman air tanah dari permukaan tanah kurang dari $50 \mathrm{~cm}$, dan 4) tipe D, lahan yang tidak pernah terluapi air pasang dan air tanahnya lebih dalam dari $50 \mathrm{~cm}$ (Widjaja-Adhi et al. 1992).

Pengembangan lahan pasang surut untuk usaha pertanian menghadapi beberapa kendala, baik teknis (biofisik), sosial, ekonomi maupun budaya (Abdurachman dan Suriadikarta 2000). Kendala pengembangan ubikayu di lahan pasang surut adalah tanah yang umumnya bersifat masam ( $\mathrm{pH} \mathrm{4-5)} \mathrm{dengan} \mathrm{kejenuhan} \mathrm{Al}$ tinggi (>40\%), kandungan hara Fe dan Mn tinggi sehingga menghambat pertumbuhan akar tanaman, serta ketersediaan hara N, P, K, Ca, dan Mg rendah (Susilawati et al. 2016). Pada lahan pasang surut dan lahan masam, penggunaan varietas ubikayu adaptif, pemberian amelioran tanah, pupuk NPK yang tepat, pupuk hayati penambat $\mathrm{N}$ dan pelarut/penambang fosfat. Pendekatan untuk mengatasi kondisi lahan tersebut antara lain dengan penerapan pemupukan berimbang yang mencakup hara makro, mikro dan pupuk organik. Salah satu komponen penting teknologi budidaya ubikayu adalah pemupukan, kecukupan hara merupakan faktor kunci yang menentukan kuantitas dan kualitas hasil ubikayu. Kadar pati merupakan unsur utama dalam umbi tanaman ubikayu (NRDC, 2003).

Untuk berproduksi tinggi ubikayu memerlukan hara yang berimbang. Imbangan dan nisbah keharaan berbeda untuk masing-masing tanaman. Hasil ubikayu 27,25 t/ha akan menyerap unsur hara masing-masing $135,5 \mathrm{~kg} \mathrm{~N}, 43,25 \mathrm{~kg}$ P2O5, $163 \mathrm{~kg} \mathrm{K2O}, 73 \mathrm{~kg} \mathrm{MgO}$, dan 10,75 kg S atau 28,42\% N, 9,07\% P2O5, 34,19\% $\mathrm{K} 2 \mathrm{O}, 15,31 \% \mathrm{MgO}, 19,82 \% \mathrm{CaO}$, dan 6,08\% S. Tanaman ubikayu menyerap hara mikro terutama $\mathrm{Mn}$ dan $\mathrm{Zn}$ cukup tinggi (Halliday, 1992). Untuk itulah diperlukan dosis pupuk yang sesuai dengan spesifikasi kebutuhan tanaman ubikayu dilahan pasang surut. Wahyuningsih dan Sutrisno, 2018 melaporkan bahwa hasil penelitian ubikayu di lahan pasang surut menunjukkan perbedaan pertumbuhan vegetatif biomass tanaman dan hasil umbi pada varietas. Varietas gajah mampu menghasilkan bobot umbi segar paling tinggi mencapai 36,4 t/ha. Peningkatan dosis pupuk juga meningkatkan pertumbuhan vegetatif dan hasil umbi. Hasil umbi paket teknologi budidaya alternatif input tinggi (300 kg N + $200 \mathrm{~kg}$ P2O5 + 300 kg K2O + $500 \mathrm{~kg}$ Dolomit) menghasilkan bobot umbi segar paling tinggi yaitu sebesar 37,5 t/ha.

Penelitian ini bertujuan untuk mengetahui pengaruh pupuk NPK dalam meningkatkan pertumbuhan dan hasil tanaman ubikayu di lahan pasang surut.

\section{METODE PENELITIAN}

Penelitian dilaksanakan di lahan masam pasang surut Desa Sidomulyo Kecamatan Wanaraya Kabupaten Barito Kuala Kalimantan Selatan pada bulan Februari-November tahun 2017. Varietas ubikayu ditanam dilahan petani pada ketinggian sekitar $4 \mathrm{~m}$ dpl. Sebelum tanam lahan diolah dan diratakan menggunakan hand traktor kemudian digulud secara manual dengan lebar guludan 1 meter dan jarak antar gulud sekitar $25 \mathrm{~cm}$. Percobaan terdiri dari dua faktor perlakuan. Faktor pertama adalah dua varietas ubikayu yaitu V1: Varietas lokal (Gajah) dan V2 varietas lokal (Kristal) sedangkan faktor kedua adalah empat level dosis pupuk NPK (P1=0 kg/ha), (P2 $=400 \mathrm{~kg} / \mathrm{ha}),(\mathrm{P} 3=800 \mathrm{~kg} / \mathrm{ha}),(\mathrm{P} 4=1200 \mathrm{~kg} / \mathrm{ha})$.

Percobaan menggunakan rancangan strip plot dengan varietas sebagai faktor horizontal, dosis pupuk sebagai faktor vertikal dan percobaan diulang tiga kali. Setiap satuan petak percobaan berukuran 5 x $5 \mathrm{~m} 2$ atau empat guludan dengan panjang 5 meter. Jarak tanam 1.25 x $1 \mathrm{~m} 2$ atau 20 tanaman per petak percobaan. Stek ubikayu dipotong menggunakan gergaji dengan ukuran panjang stek $20 \mathrm{~cm}$ dan ditanam secara manual. Aplikasi pupuk NPK dilakukan dua kali yaitu pada umur 2 mst (minggu setelah tanam) dan 3 bulan. Pengendalian gulma dilakukan pada saat tanaman umur 2 dan 4 bst (bulan setelah tanam). Setelah 4 bulan kanopi tanaman sudah 
rapat dan menutup sehingga gulma sudah tidak tumbuh. Pengendalian hama tidak dilakukan karena tanaman tumbuh dalam kondisi normal tanpa serangan hama yang melebihi ambang batas kendali. Tanaman dipanen pada saat sudah berumur 10 bst yang ditandai dengan tanaman sudah tidak menunjukkan pertumbuhan.

Pengamatan dilakukan terhadap komponen vegetatif dan generatif pada saat tanaman di panen. Lima tanaman sampel per petak diambil secara acak, dicabut, dan diamati sesuai parameter yang sudah ditentukan. Komponen pertumbuhan yang diamati yaitu tinggi tanaman, diameter batang, bobot biomas tanaman,jumlah umbi besar, jumlah umbi kecil, panjang umbi besar, panjang umbi kecil, diameter umbi besar, diameter umbi kecil, jumlah umbi total, bobot umbi besar, bobot umbi kecil, dan bobot umbi total.

Analisis data dilakukan menggunakan software statistic tools for agricultural research (STAR) yang dikeluarkan oleh IRRI Philipina. Data dianalisis ragam untuk menentukan signifikansi pengaruh perlakuan. Jika perlakuan berpengaruh nyata terhadap parameter yang diamati, analisis dilanjutkan dengan pemisahan nilai tengah menggunakan uji beda nyata terkecil $\alpha 0.05$.

\section{HASIL DAN PEMBAHASAN}

Hasil

Perbedaan varietas tidak menunjukkan perbedaan pertumbuhan vegetatif tanaman ubikayu. Selisih tinggi tanaman antara varietas Gajah dan Kristal hanya $4 \mathrm{~cm}$ sedangkan selisih bobot biomassa tanaman hanya $1 \mathrm{~kg}$ dan pada ukuran diameter batang selisihnya hanya $0,5 \mathrm{~mm}$. Melihat kondisi pertumbuhan vegetatif tanaman, pertumbuhan tanaman sudah cukup bagus. Hal ini sesuai dengan hasil evaluasi plasma nutfah yang menunjukkan hasil bahwa ukuran tinggi tanaman ubikayu rata-rata antara 250-350 cm sedangkan untuk ukuran diameter batang berkisar antara 12-26 mm (Zuraida, 2016).

Aplikasi pupuk NPK phonska efektif meningkatkan pertumbuhan vegetatif tanaman ubikayu. Peningkatan pertumbuhan terlihat pada karakter tinggi tanaman, diameter batang dan bobot biomassa tanaman. Pada perlakuan kontrol, tinggi tanaman, diameter batang dan bobot biomass menunjukkan pertumbuhan paling rendah sedangkan pemberian pupuk NPK sebesar $400 \mathrm{~kg} / \mathrm{ha}$ menghasilkan peningkatan tinggi tanaman, diameter batang dan biomasa tanaman berturut-turut sebesar 13\%, 31\%, dan 104\%. Peningkatan dosis pupuk NPK hingga $800 \mathrm{~kg} / \mathrm{ha}$ menghasilkan pertumbuhan tinggi tanaman, diameter batang, dan biomasa tanaman sebesar 24\%, 37\%, dan $133 \%$ dibandingkan dengan pertumbuhan pada perlakuan kontrol (0 kg/ha). Pemberian dosis pupuk NPK hingga $1200 \mathrm{~kg} / \mathrm{ha}$ tidak efektif lagi untuk meningkatkan pertumbuhan vegetatif ubikayu (Tabel 1).

Peningkatan pertumbuhan optimal tinggi tanaman, diameter batang dan bobot biomasa ubikayu pada dosis $800 \mathrm{~kg} / \mathrm{ha}$ menunjukkan bahwa kebutuhan unsur hara makro (NPK) dan kemampuan tanaman ubikayu memanfaatkan unsur hara makro NPK yang diberikan sudah mencapai batas maksimum. Peningkatan pemberian jumlah pupuk NPK sudah tidak bermanfaat untuk meningkatkan pertumbuhan vegetatif tanaman pada lahan rawa pasang surut Kalimantan Selatan. Hasil penelitian ini seiring dengan hasil penelitian lain yang menyatakan bahwa pemberian pupuk NPK $800 \mathrm{~kg} / \mathrm{ha}$ efektif menghasilkan pertumbuhan vegetatif secara maksimal (Shanti dan Nirmala 2018).

Tabel 1. Tinggi tanaman, Diameter Batang, dan Bobot Brangkasan Dua Varietas Ubikayu pada Empat Dosis Pupuk NPK di Lahan Pasang Surut Barito Kuala Kalimantan selatan, 2017

\begin{tabular}{cccc}
\hline $\begin{array}{c}\text { Varietas/ } \\
\text { Pupuk }\end{array}$ & $\begin{array}{c}\text { Tinggi } \\
\text { Tanaman }\end{array}$ & $\begin{array}{c}\text { Diameter } \\
\text { Batang }(\mathrm{mm})\end{array}$ & $\begin{array}{c}\text { Bobot } \\
\text { Biomas }\end{array}$ \\
\hline Varietas & & & $12.65 \mathrm{a}$ \\
\hline Gajah & $290.52 \mathrm{a}$ & $20.22 \mathrm{a}$ & $11.28 \mathrm{a}$ \\
Kristal & $286.99 \mathrm{a}$ & $20.73 \mathrm{a}$ & 11.97 \\
\hline Rerata & 288.75 & 20.47 & 19.42 \\
CV & 4.39 & 8.18 & $5.92 \mathrm{c}$ \\
\hline Pupuk & & & $12.10 \mathrm{~b}$ \\
\hline $\mathrm{kg} / \mathrm{ha}$ & $249.95 \mathrm{c}$ & $16.40 \mathrm{~b}$ & $14.50 \mathrm{a}$ \\
$400 \mathrm{~kg} / \mathrm{ha}$ & $282.78 \mathrm{~b}$ & $21.00 \mathrm{a}$ & $15.34 \mathrm{a}$ \\
$800 \mathrm{~kg} / \mathrm{ha}$ & $310.33 \mathrm{a}$ & $22.02 \mathrm{a}$ & 11.97 \\
$1200 \mathrm{~kg} / \mathrm{ha}$ & $311.95 \mathrm{a}$ & $22.47 \mathrm{a}$ & 18.12 \\
\hline Rerata & 288.75 & 20.47 & 8.58 \\
\hline CV & 7.28 & $\mathrm{~B}$ & $\mathrm{~B}$ \\
\hline
\end{tabular}

Keterangan: Nilai yang diikuti huruf yang sama dinyatakan tidak berbeda berdasarkan uji BNT 5\%

Perbedaan varietas tidak menunjukkan perbedaan terhadap jumlah umbi namun menunjukkan perbedaan terhadap pertumbuhan ukuran panjang umbi. Varietas V2 cenderung memiliki ukuran umbi besar dan kecil lebih panjang daripada varietas V1. Varietas V2 menghasilkan ukuran umbi besar 10\% lebih panjang dibandingkan 
V1 dan ukuran umbi kecil varietas V2 dapat mencapai $15 \%$ lebih panjang daripada ukuran umbi kecil varietas V1 (Tabel 2). Perbedaan kemampuan menghasilkan ukuran umbi kemungkinan dipengaruhi oleh faktor genetik tanaman dan interaksinya dengan lingkungan tumbuhnya (Herman, et al. 2016)

Pemberian pupuk NPK berdampak pada pertambahan dan pertumbuhan umbi. Jumlah umbi besar, jumlah umbi kecil dan panjang umbi bertambah signifikan pada tanaman yang mendapatkan pupuk NPK namun jumlah maksimum tiap karakter diperoleh pada perlakuan dosis pupuk yang berbeda. Jumlah umbi besar paling banyak diperoleh pada perlakuan pupuk NPK $400 \mathrm{~kg} / \mathrm{ha}$. Peningkatan dosis pupuk NPKS menjadi $800 \mathrm{~kg} / \mathrm{ha}$ atau lebih sudah tidak menambah jumlah umbi besar yang terbentuk. Persentase peningkatan jumlah umbi pada perlakuan NPK 400 maupun $800 \mathrm{~kg} / \mathrm{ha}$ mencapai sekitar 38-43\% dibandingkan dengan tanpa pupuk NPK. Kondisi ini berbeda dengan karakter umbi kecil. Pada karakter umbi kecil jumlah maksimum umbinya diperoleh pada dosis pupuk NPK $800 \mathrm{~kg} / \mathrm{ha}$ dan tidak meningkat lagi dengan adanya peningkatan dosis pupuk NPKS yang diberikan. Peningkatan jumlah umbi kecil akibat pemberian pupuk hingga 400 dan 800 kg/ha mencapai 7 hingga $29 \%$ dibandingkan perlakuan tanpa pupuk NPK.

Panjang umbi besar maksimum diperoleh pada perlakuan pupuk NPK $800 \mathrm{~kg} / \mathrm{ha}$ dengan panjang maksimum $34.35 \mathrm{~cm}$. Pemberian dosis pupuk NPK lebih rendah $(400 \mathrm{~kg} / \mathrm{ha})$ menghasilkan ukuran panjang umbi besar lebih rendah yaitu $32,10 \mathrm{~cm}$ sedangkan pemberian pupuk NPK lebih tinggi sudah tidak meningkatkan ukuran umbi besar. Pada perlakuan tanpa pupuk NPK, ukuran umbi besar hanya mencapai 28,47 cm. Hasil ini menunjukkan bahwa aplikasi pupuk NPK 400 hingga $800 \mathrm{~kg} / \mathrm{ha}$ meningkatkan ukuran umbi besar antara 12-20\%. Pada karakter umbi kecil, ukuran umbi maksimum diperoleh hanya dengan pupuk NPK 400 $\mathrm{kg} /$ ha dengan peningkatan ukuran umbi sekitar 14\% dibandingkan tanpa pemberian pupuk NPK (Tabel 2).

Tabel 2. Jumlah Umbi dan Panjang Umbi Dua Varietas Ubikayu dan Empat Dosis Pupuk NPK di Lahan Pasang Surut Barito Kuala Kalimantan Selatan, 2017

\begin{tabular}{|c|c|c|c|c|}
\hline $\begin{array}{c}\text { Varietas/ } \\
\text { Pupuk }\end{array}$ & $\begin{array}{c}\text { Jumlah Umbi } \\
\text { Besar }(\sqrt{ })\end{array}$ & $\begin{array}{c}\text { Jumlah Umbi } \\
\text { Kecil }(\sqrt{ })\end{array}$ & $\begin{array}{c}\text { Panjang Umbi } \\
\text { Besar }\end{array}$ & $\begin{array}{c}\text { Panjang Umbi } \\
\text { Kecil }\end{array}$ \\
\hline \multicolumn{5}{|l|}{ Varietas } \\
\hline Gajah & $5.58 a$ & $4.60 \mathrm{a}$ & $30.20 \mathrm{~b}$ & $16.48 b$ \\
\hline Kristal & $6.18 \mathrm{a}$ & $5.55 \mathrm{a}$ & $33.73 a$ & $19.09 a$ \\
\hline Rerata & 5.88 & 5.08 & 31.96 & 17.79 \\
\hline KK & 13.84 & 13.35 & 7.52 & 12.63 \\
\hline \multicolumn{5}{|l|}{ Pupuk } \\
\hline $0 \mathrm{~kg} / \mathrm{ha}$ & $4.48 b$ & $4.32 b$ & $28.47 c$ & $16.13 b$ \\
\hline $400 \mathrm{~kg} / \mathrm{ha}$ & $6.22 \mathrm{a}$ & $4.65 b$ & $32.10 \mathrm{~b}$ & $18.40 \mathrm{a}$ \\
\hline $800 \mathrm{~kg} / \mathrm{ha}$ & $6.42 \mathrm{a}$ & $5.57 a$ & $34.35 a$ & 18.38a \\
\hline $1200 \mathrm{~kg} / \mathrm{ha}$ & $6.40 \mathrm{a}$ & $5.77 \mathrm{a}$ & $32.93 \mathrm{ab}$ & $18.23 \mathrm{a}$ \\
\hline Rerata & 5.88 & 5.08 & 31.96 & 17.79 \\
\hline KK & 8.58 & 9.46 & 6.86 & 8.98 \\
\hline
\end{tabular}

Pertumbuhan diameter umbi besar maupun umbi kecil sangat dipengaruhi oleh varietas dan perlakuan pupuk NPK. Varietas Gajah menghasilkan pertumbuhan diameter umbi besar dan kecil lebih besar ketika memperoleh perlakuan pupuk NPK. Pada perlakuan pupuk NPK $400 \mathrm{~kg} / \mathrm{ha}$, ukuran diameter umbi besar bertambah dari 48,13 mm menjadi 53,45 mm atau bertambah 11\%. Peningkatan dosis pupuk NPK lebih dari 400 $\mathrm{kg} / \mathrm{ha}$ sudah tidak lagi meningkatkan pertambahan diameter umbi besar. Pada karakter diameter umbi kecil, pemberian pupuk NPK $400 \mathrm{~kg} / \mathrm{ha}$ meningkatkan ukuran diameter umbi sebesar $9 \%$ dan juga tidak mengalami peningkatan lebih tinggi ketika dosis pupuk NPK ditingkatkan. Kondisi berbeda terjadi pada varietas Kristal. Pemberian pupuk dari dosis terendah hingga tertinggi tidak signifikan meningkatkan ukuran diameter umbi baik besar maupun kecil.

Pada perbandingan antarvarietas, Varietas Gajah menghasilkan ukuran umbi 25,7\% lebih besar dibandingkan Kristal dengan rata-rata diameter umbi masing masing sebesar 51,9 dan 41,3 mm. Respon yang sama juga terjadi pada komponen diameter umbi kecil. Ukuran diameter umbi kecil pada Gajah sebesar 37,9 mm sedangkan pada Kristal sebesar 31,12 mm atau terjadi perbedaan ukuran diameter sebesar 21,8\%. Varietas Kristal tampaknya lebih responsif terhadap pemberian pupuk NPK. Tanpa aplikasi pupuk NPK, jumlah umbi total yang dihasilkan oleh kedua varietas relatif setara namun ketika diberi input pupuk NPK dosis $400 \mathrm{~kg} / \mathrm{ha}$ hingga $1200 \mathrm{~kg} / \mathrm{ha}$ varietas Kristal menghasilkan jumlah umbi total lebih banyak dibandingkan varietas Gajah. Pada perlakuan dosis pupuk $400 \mathrm{~kg} / \mathrm{ha}$, varietas Kristal juga sudah menunjukkan peningkatan jumlah umbi 
cukup signifikan dari 8,36 menjadi 11,83 sedangkan pada varietas Gajah jumlah umbi total yang dihasilkan masih relatif setara hingga dosis pupuk NPK $800 \mathrm{~kg} / \mathrm{ha}$.

Tabel 3. Diameter Umbi dan Jumlah Umbi Total Dua Varietas Ubikayu dan Empat Dosis Pupuk NPK di Lahan Pasang Surut Barito Kuala Kalimantan Selatan, 2017

\begin{tabular}{|c|c|c|c|c|c|c|}
\hline \multirow{2}{*}{$\begin{array}{l}\text { Varietas vs } \\
\text { pupuk }\end{array}$} & \multicolumn{2}{|c|}{ Diameter Umbi Besar } & \multicolumn{2}{|c|}{ Diameter Umbi Kecil } & \multicolumn{2}{|c|}{ Jumlah Umbi Total } \\
\hline & Gajah & Kristal & Gajah & Kristal & Gajah & Kristal \\
\hline $0 \mathrm{~kg} / \mathrm{ha}$ & 48.13ba & 42.43ab & $35.12 \mathrm{ba}$ & $32.40 \mathrm{ab}$ & $9.23 \mathrm{ba}$ & 8.36 ba \\
\hline $400 \mathrm{~kg} / \mathrm{ha}$ & 53.45aа & $41.11 \mathrm{ab}$ & 38.41aа & $30.82 \mathrm{ab}$ & $9.90 \mathrm{abb}$ & 11.83 аa \\
\hline $800 \mathrm{~kg} / \mathrm{ha}$ & 53.11aа & $40.52 \mathrm{ab}$ & 38.87aа & $30.04 \mathrm{ab}$ & $10.43 \mathrm{abb}$ & 13.53 aа \\
\hline $1200 \mathrm{~kg} / \mathrm{ha}$ & 53.13aа & $41.16 \mathrm{ab}$ & 39.22aа & $31.22 \mathrm{ab}$ & $11.13 \mathrm{ab}$ & 13.20 aа \\
\hline Rerata & \multicolumn{2}{|c|}{46.63} & \multicolumn{2}{|c|}{34.52} & \multicolumn{2}{|c|}{10.95} \\
\hline KK & \multicolumn{2}{|c|}{5.95} & \multicolumn{2}{|c|}{6.29} & \multicolumn{2}{|c|}{13.72} \\
\hline
\end{tabular}

Meskipun varietas Gajah memperoleh jumlah umbi total lebih banyak dan ukuran umbi juga lebih panjang, bobot umbi total varietas Gajah ternyata lebih besar daripada varietas Kristal. Pada kondisi ini bobot umbi total lebih ditentukan oleh ukuran besar umbi atau diameter umbi daripada oleh jumlah umbi dan panjang umbi. Bobot umbi total pada varietas Gajah diperoleh $14,87 \mathrm{~kg}$ per 5 tanaman, $16 \%$ lebih tinggi dibandingkan varietas Kristal yang hanya memperoleh bobot umbi total 12,78 kg per 5 tanaman. Hasil ini juga didukung dangan bobot umbi besar varietas Gajah yang lebih tinggi daripada Kristal sedangkan bobot umbi kecil tidak berpengaruh besar terhadap perbedaan bobot umbi total per 5 tanaman (Tabel 4).

Aplikasi pupuk NPK berpengaruh terhadap bobot umbi besar, bobot umbi kecil dan bobot umbi total. Pada perlakuan tanpa pupuk NPK, bobot umbi besar, bobot umbi kecil dan bobot umbi total berturut-turut hanya 1,39 $\mathrm{kg}, 0,48 \mathrm{~kg}$, dan 1,89 kg/tanaman namun ketika memperoleh pupuk NPK $400 \mathrm{~kg} / \mathrm{ha}$, bobot umbi besar, kecil dan total menjadi $2,35 \mathrm{~kg}, 0,58 \mathrm{~kg}$, dan 2,94 kg/tanaman atau meningkat berturut-turut sebesar $69 \%, 22 \%$, dan $57 \%$. Peningkatan dosis pupuk NPK melebihi $400 \mathrm{~kg} / \mathrm{ha}$ tidak efektif lagi meningkatkan bobot umbi tanaman ubikayu pada percobaan ini (Tabel 4).

Tabel 4. Bobot Umbi Dua Varietas Ubikayu dan Empat Dosis Pupuk NPK di Lahan Pasang Surut Barito Kuala Kalimantan Selatan, 2017

\begin{tabular}{|c|c|c|c|}
\hline Varietas & Bobot Umbi Besar $(\sqrt{ })$ & $\begin{array}{l}\text { Bobot Umbi Kecil } \\
\qquad(\sqrt{ })\end{array}$ & $\begin{array}{c}\text { Bobot } \\
\text { Umbi Total }\end{array}$ \\
\hline Gajah & $2.37 \mathrm{a}$ & $0.60 \mathrm{a}$ & $2.97 a$ \\
\hline Kristal & $1.92 \mathrm{~b}$ & $0.64 a$ & $2.56 \mathrm{~b}$ \\
\hline Rerata & 2.14 & 0.62 & 2.76 \\
\hline KK & 10.96 & 14.21 & 20.12 \\
\hline \multicolumn{4}{|l|}{ Pupuk } \\
\hline $0 \mathrm{~kg} / \mathrm{ha}$ & $1.39 \mathrm{~b}$ & $0.48 c$ & $1.89 \mathrm{~b}$ \\
\hline $400 \mathrm{~kg} / \mathrm{ha}$ & $2.35 \mathrm{a}$ & $0.58 \mathrm{bc}$ & $2.94 \mathrm{a}$ \\
\hline $800 \mathrm{~kg} / \mathrm{ha}$ & $2.41 \mathrm{a}$ & $0.73 a$ & $3.13 a$ \\
\hline $1200 \mathrm{~kg} / \mathrm{ha}$ & $2.42 \mathrm{a}$ & $0.70 \mathrm{ab}$ & $3.12 \mathrm{a}$ \\
\hline Rerata & 2.14 & 0.62 & 2.76 \\
\hline KK & 12.86 & 12.26 & 17.81 \\
\hline
\end{tabular}

\section{Pembahasan}

Aplikasi pupuk NPK efektif meningkatkan hasil umbi ubikayu. Peningkatan hasil umbi disebabkan karena tanaman menghasilkan pertumbuhan vegetatif cukup tinggi pada karakter tinggi tanaman, diameter batang, dan biomassa tanaman (Tabel 1). Pemberian pupuk NPK menyebabkan tanaman memacu pertumbuhan dan perkembangan sel untuk meningkatkan pertumbuhan dan perkembangan organ tanaman. Akibatnya organ tanaman seperti batang tanaman ubikayu tumbuh semakin tinggi, jumlah daun terbentuk semakin banyak, 
ukuran permukaan daun semakin luas, warna daun semakin hijau, tangkai daun lebih besar dan panjang yang akhirnya menyebabkan biomasa tanaman semakin berat.

Pertambahan jumlah daun, luas permukaan daun, dan warna daun yang semakin hijau menunjukkan tanaman memiliki jumlah klorofil lebih banyak. Organel klorofil dimanfaatkan tanaman untuk proses fotosintesis menghasilkan karbohidrat. Karbohidrat yang tersintesis kemudian ditransfer dan disimpan di dalam umbi dalam bentuk pati. Ketika jumlah klorofil semakin banyak, proses fotosintesis kemungkinan semakin meningkat dan jumlah pati yang disimpan di dalam umbi semakin banyak. Jumlah umbi terbentuk semakin banyak, ukuran umbi semakin panjang dan besar dan akhirnya memiliki bobot umbi semakin berat. Kondisi ini terlihat pada tanaman yang memperoleh pupuk NPK yang memiliki jumlah umbi, ukuran umbi dan bobot umbi lebih besar dibandingkan jumlah, ukuran dan bobot umbi pada tanaman tanpa pemberian pupuk NPK. Peningkatan pertumbuhan karakter vegetatif tersebut memungkinkan tanaman menghasilkan fotosintat lebih banyak yang kemudian dipindahkan dan disimpan di dalam umbi. Akibatnya jumlah umbi terbentuk semakin banyak dan berukuran besar. Hal ini terlihat pada karakter jumlah umbi, panjang umbi, diameter umbi dan bobot umbi pertanaman yang lebih banyak dan berukuran besar pada tanaman yang diberi pupuk NPK dibandingkan tanaman tanpa pupuk NPK (Tabel 2, 3,4).

Peningkatan dosis pupuk NPK tidak selalu meningkatkan produktivitas hasil ubikayu. Hal ini disebabkan karena kemampuan tanaman dalam memanfaatkan unsur hara tersedia dipengaruhi oleh banyak faktor lingkungan lain seperti kemasaman tanah, ketersediaan air atau dibatasi oleh unsur hara lainnya. Jika unsur hara lainnya yang dibutuhkan tersedia terlalu sedikit atau terlalu banyak juga dapat membatasi pertumbuhan dan perkembangan tanaman. Hasil penelitian sebelumnya menyebutkan $\mathrm{pH}$ rendah membatasi pertumbuhan dan hasil tanaman ubikayu meskipun memperoleh jumlah pupuk NPK dosis tinggi (Shanti and Nirmala 2018). Begitu juga kelebihan unsur hara dan kekurangan unsur hara menjadi faktor penghambat pertumbuhan dan hasil ubikayu (Ojeniyi et al. 2012; Biratu et al. 2018).

\section{KESIMPULAN}

Perbedaan varietas menghasilkan pertumbuhan vegetatif setara namun menghasilkan pertumbuhan generatif atau hasil umbi berbeda. Varietas gajah memberikan hasil umbi lebih tinggi (sekitar 15\%) dibandingkan varietas Kristal yang merupakan varietas lokal Kalimantan. Aplikasi pupuk efektif meningkatkan pertumbuhan vegetatif dan generatif tanaman namun peningkatan dosis tidak selalu meningkatkan pertumbuhan dan hasil ubikayu. Dosis terbaik untuk memberikan pertumbuhan dan hasil tertinggi diperoleh pada dosis 400 $\mathrm{kg} / \mathrm{ha}$.

\section{DAFTAR PUSTAKA}

Abdurachman, A. dan D.A. Suriadikarta. 2000. Pemanfaatan laha rawa eks PLG Kalimantan Tengah untuk pengembangan pertanian berwawasan lingkungan. Jurnal Penelitian dan Pengembangan Pertanian, 19(3): 77-81.

Badan Pusat Statistik. 2016. Produksi, luas panen dan produktivitas ubi kayu menurut provinsi, 2010-2015. (Diakses 13 Juli 2021).

Balai Penelitian Tanah. 2012. Laporan Tahunan. Balai Besar Penelitian dan Pengembangan Sumberdaya Lahan Pertanian, Bogor.

Biratu, Gizachew Kebede, Eyasu Elias, Pheneas Ntawuruhunga, and Gudeta W. Sileshi. 2018. "Cassava Response to the Integrated Use of Manure and NPK Fertilizer in Zambia." Heliyon 4(8):1-13.

Halliday, D.J. 1992. IFA World Fertilizer Use Manual. International Fertilizer Industry Association. Germany. $632 \mathrm{p}$.

Herman, Herman, Dewi Indriyani, Roslim, and Ingga Yurisna Fitriani. 2016. Respon Genotipe Ubi Kayu (Manihot Esculenta Crantz) Terhadap Dosis Pupuk Kandang Kotoran Sapi Taluk Kuantan. Jurnal Dinamika Pertanian, 32(2):135-42.

James, G and G. Byju. 2010. Sustainable cassava production for food security in the context of ensuing climate change. InR.B. Mohamad et al.(Eds) Proceeding of International Conference on Food Security during Challenging Times. 5-7thJuly 2010. Universiti Putra Malaysia. Serdang, Selangor Malaysia. p.48-50.

Mulyani A, Nursyamsi D, Harnowo D. 2017. Potensi dan tantangan pemanfaatan lahan suboptimal untuk tanaman aneka kacang dan umbi. Hlm.16-30. Dalam: Rahmianna AA, Harnowo D, Sholihin, Nugrahaeni N, Taufiq A, Suharsono, Yusnawan E, Ginting E, Rozi F, Hermanto (eds). Prosiding 
Seminar Nasional Hasil Penelitian Tanaman Aneka Kacang dan Umbi Tahun 2016. Pusat Penelitian dan Pengembangan Tanaman Pangan, Bogor.

NRDC (National Research Development Corporation). 2003. Cassava starch. http://www.nrdccindia.com/pages/cassstar.htm. (Diakses 4 Juli 2021).

Ojeniyi, S. O., S. A. Adejoro, O. Ikotun, and Amusan O. 2012. Soil and plant nutrient composition, growth and yield of cassava as influenced by integrated application of NPK fertilizer and poultry manure. New York Science Journal 5(9): 62-68.

Saleh N. 2012. Pengendalian hama penyakit terpadu pada ubikayu. Iptek Pertanian Seri 1. Jakarta (ID): Badan Penelitian dan Pengembangan Pertanian.

Susilawati A, Nursyamsi D, Syakir M. 2016. Optimalisasi penggunaan lahan rawa pasang surut mendukung swasembada pangan nasional. Jurnal Sumberdaya Lahan, 10(1): 51-64.

Shanti, Ratna, and Ratna Nirmala. 2018. Respon Tiga Varietas Ubi Kayu (Manihot esculenta. L) Terhadap Pemupukan di Kutai Timur. Jurnal Pertanian Terpadu, 6(1):46-58.

Widjaja-Adhi, I.P.G, K. Nugroho, D. Ardi, dan A.S. Karama. 1992. Sumber daya lahan rawa: potensi, kebutuhan dan pemanfaatannya. Dalam Risalah Pertemuan Nasional Pengembangan Pertanian Lahan Rawa Pasang Surut dan Lebak, Cisarua, 3-4 Maret 1992. Pusat Penelitian dan Pengembangan Tanaman Pangan, Bogor.

Wahyuningsih S, dan Sutrisno. 2018. Pengaruh Pupuk Dan Varietas Pada Pertumbuhan Dan Hasil Ubikayu Di Lahan Pasang Surut Kalimantan Selatan Prosiding Seminar Nasional "Pembangunan Pertanian Indonesia Dalam Memperkuat Lumbung Pangan, Fundamental Ekonomi dan Daya Saing Global”. UPN Yogyakarta. 1-12 hal.

Zuraida, Nani. 2016. Karakterisasi Beberapa Sifat Kualitatif dan Kuantitatif Plasma Nutfah Ubi Kayu (Manihot esculenta Crantz.). Buletin Plasma Nutfah, 16(1):49-56. 